\section{The Relationship between Religiosity, Self- Interest, and Impulse Buying: an Islamic Perspective}

\section{Relationship between

\section{Arif Hoetoro}

Faculty of Economics and Business, Brawijaya University, Indonesia hoetoro@ub.ac.id

\section{Muhammad Said Hannaf}

Faculty of Economics and Business, Brawijaya University, Indonesia

\begin{abstract}
The expansion of e-commerce dramatically changes the spending patterns which are found a significant number of impulse buying. Practical method and easy way to buy specific goods from e-commerce might be an important factor why customers spent their money more impulsively. Researches on this phenomenon showed that psychological values emerged from religiusity condition and self-interest encouragement play as self-regulation for controlling impulsive buying behavior. Viewed from Islamic economic perspective, this study seeks to configurate self-interest (al-nafs) into three levels namely al-nafs al-ammarah, al-nafs al-lawwamah, and al-nafs al-muthmainnah when al-nafs involved in online impulse buying. The first two layers of al-nafs refer to the level of self-interest which are material oriented, whereas the last one represents the highest level of self-interest which is spiritual oriented. By employing 134 repondents from e-commerce customers in Jakarta, the research findings revealed that there was no relationship between religiusity and alnafs al-ammarah and al-nafs al-lawwamah. However, al-nafs al-ammarah and al-nafs al-lawwamah positively influenced impulse buying. Meanwhile, there was strong relationship between religiusity and al-nafs al-muthmainnah in which this highest level of self-interest did not have relationship with impulse buying. These research findings have important implications that in order to regulate impulsive buying behavior, customers should control their self-interest and make it to be alnafs al-muthmainnah.
\end{abstract}

Keywords:

Impulse buying, E-commerce, Religiousity, Self-interest, Transformation of al-nafs

\section{INTRODUCTION}

Recently, e-commerce has developed rapidly and atracted customers to online shopping more impulsively (Akram et. al., 2016). According to Katadata (2018) the number of online shoppers in Indonesia has reached 44 milion buyers with total sale around 8.5 billion dollars. Among e-commerce providers, Lazada, Tokopedia, Elevania, Bukalapak, Blibli, and Shopee are 
IQTISHADIA

12,1

42

the most famous shop for online customers in Indonesia. Due to its advantage in allowing customers to electronically exchange goods and services with no barrier, time, and distance, e-commerce has successfully attracted so many customers and it is predicted to accelerate (Franco and Bulomine, 2016).

Commonly impulse buying refers to a sudden desire of customer to make unplanned purchase (Mathai and Haridas, 2014). In the context of online shopping, impulse buying was defined as the spur of the moment buying without a priori shopping intension (Singh and Verma, 2018) that reflects an integrated manifestation of rational and irrational behavior (ShihLo et. al., 2016). By the massive use of internet, people make purchase online to conserve time and efforts. Many of them make internet to espouse the individuality culture (Akram et. al., 2018). However, a classical work of Rook and Fisher (1995) stated that impulse buying has been associated with "being bad" that lead to negative consequences in the areas of personal finance, post purchase satisfaction, social reaction, and other personal traits. Furthermore, the buying causes to myopic and inconsistent behaviour as customers buy a product with unintended, immediate, and unreflective purchases (Badgaiyan et. al., 2016).

Viewed from psychological aspects, Verplanken and Sato (2011) pointed out that impulse buying can lead customers to paradoxical behavior; in one side impulse buying is associated with pleasure but in another side it is related to negative emotions. Hence, self-regulation is needed to control customers whether they buy impulsively or they should be prevented against impulsivity.

This paper come up with a notion that part of self-regulation in impulse buying is driven by religiusity quality and customer's self-interest. In neoclassical economics, self-interest has formed individual's rationality and become a driving motive of individual's action (Vriend, 1996). However, we configurate this self-interest into three layers namely al-nafs al-ammarah, al-nafs al-lawwamah, and al-nafs al-muthmainnah (Hoetoro, 2017) and aim to search their roles in online impulse buying. Some verses in the Holy Quran shows this configuration, and it is assumed that all these configuration of self-interest will influence human behavior.

For the basis of this configuration we assumed that along with rationality in fact religiousity also plays another role for individual's action. This paper then examines the relationship between religiousity, self-interest configuration and online impulse buying. Our study is expected to contribute 
to customer field by investigating this relationship that have attracted little attention in the scientific research.

\section{LITERATURE REVIEW}

\section{Religiosity and Online Impulse Buying}

Recently, researches on economic behavior proved that religious values influence economic activity. These values affect economic activities by fostering individual's traits such as work ethic, thrift, and honesty (McCleary and Barro, 2006). In Islam, all these traits called as akhlaq guides every muslim to fit their consumption behavior with moral utility (Alam et.al, 2011) such as stated in the Holy Quran surat al-Isra [17]: 26-27 that Allah prohibits muslims to spend extravagantly. Besides, every muslim must also spend their money in accordance with his needs and ability. They are prohibited to consume goods that gives them debt and another financial difficulty. Hence, Borzooei and Asgari (2014) emphasized that religion becomes the most influential factor that makes the consumers to decide their purchase intention. In adition, Musadik and Azmi (2017) stated there are five types of religious factors that influence customer behavior namely: religious affiliation, religious commitment, religious motivation, religious knowledge, and awareness of the social consequences of following a religion.

Religiosity is the centre of religion. It refers to the religous commitment in which Worthington et. al. (2003) defined it as "the degree to which a person adheres to his or her religious values, beliefs, and practices and uses them in daily living”. He furthemore found that there was differences those are had commitment to religion and those who are moderately to less religiously committed. In line with the rapid devlopment of e-commerce the role of religiosity seems to be more important whether impulse buying can be controled or not. Since impulse buying is being associated with bad behavior (Rook and Fisher, 1995), self-regulation is needed to control this bahavior (Pradipto et. al., 2016). This is because impulsive buying has been framed as result from a lack of self-control such as thinking about spending the money or down regulating elated emotions (Verplanken and Sato, 2011). Hence, religiosity takes its place as religious beliefs and norms tell the customers what is the morally right or wrong thing to do (Hofmann et. al., 2018). Gebauer et. al. (2016), however, stated that a comparatively crosscultural studies has questioned the important of religiosity. It depends on religious cultures. From Islamic perspective, Aliman et. al. (2017) found that 
IQTISHADIA

12,1

44

Islamic religiosity commitment is very important. For young-adult Muslim consumers in Malaysia, Islamic relgiosity become an essential consideration in shopping styles.

Rasearches on online impulse buying basically have been done in numerous number with various scopes and concerns. For example, Franco and Bulomine (2016) identified advantages and challenges ini e-commerce; Ling and Yazdanifard (2015) investigated internal and external factors that urge customers to spend impulsively; and Verplanken and Sato (2011) scrutinized psychological approach in impulse buying. However, researches on the relationship between Islamic religiosity and online impulse buying are limited in number.

In terms of Islamic religiosity, al-Quran and the Prophet's traditions encourage every muslim to consume moderately. It is clear that Islam commands to the believers to behave in accordance with Islamic legislation objectives (maqasid al-shariat). Within maqasid, money must be spent to fulfill the basic needs before enjoying luxury goods or other pleasure spending. In contrast, being impulsive in spending and consumption will lead consumers in bad manner such as being greedy, selfish, arrogant, as well as entraped in debt. All these are accounted as extravagant and unplanned consumption which is impermissible in Islamic teaching. However, Musadik and Azmi (2017) noted that researches on this issue and its relationship with impulse buying still need deep investigation.

\section{Religiosity and Self-Interest}

In neoclassical economics self-interest has been constructed as the heart of individual's actions. It guides to the rationality state that homo economicus consistently tends to maximize his or her utility. However, many critics on this economics foundation are claiming that people are not rational and they nor solely self-interested (Hill and Myatt, 2010). They also have plural motives that create individual behavior in both the social and economic contexts. In this regard, emotional intelligence determined individual behavior (Fiori, 2009).

While religiosity expresses an esoteric layer of psychological aspect of economic man, self-interest represents its exoteric one. Sedikides and Gebauer (2010) stated that people are motivated by their religiosity to self-enhance; their extrinsic orientation are disposed to use religion for their own ends. Spesifically, Koole et. al. (2010) proposed that religious belief leads people to 
a self-regulatory mode that is flexible, efficient, and governed by unconsious processes. In this regard, religousity may shape not only individuals' motives, but also the mechanism whereby he or she engages in motivated action. In short, religiosity in everyday languages refers to the piety on the regulations that govern man's relationship with the unseen world, especially with his Lord (Arjuna et. al., 2017).

Due to religious values are congruent with extrinsic behavior, selfinterest cannot be assumed as a single entity that drives people to simply maximize their utility. Viewed from Islamic economics perspective, selfinterest must be inherent in homo islamicus but in another form. Following Warde, Farooq (2011) identified homo islamicus as an economic individual who emphasizes on welfare and behaves altruistically according to religious norms. Hoetoro (2017) then elaborates self-interest in three configuration namely: self-material interested (al-nafs al-ammarah), self-ambiguity (al-nafs al-lawwamah), and self-theistic consciousness (al-nafs almuthmainnah). This configuration of self-interest can be found in the Holy Quran verses Yusuf [12]: 53, al-Qiyamah [75]: 2, and al-Fajr [89]: 27-28. Rothman and Coyle (2018) put al-nafs al-muthmainnah on the highest level of self-interst. It relates with ruh that tends to fitrah. Al-nafs al-lawwamah laid down in conflicting forces between qalb and $a q l$ that tries to follows fitrah. Finally, al-nafs al-ammarah tends to be material oriented and follows addunya (this life).

In the lowest level of self-interest, al-nafs al-ammarah leads people to behave in line with utility maximization principle. According to Hamzah et. al. (2010), al-nafs al-ammarah is the lowest spiritual development level and this nafs is also identified as the animal soul. In sufistic terminology, the ego-consciousness of the ordinary man is constructed as the sensuous and sensual of big "I". For example, if consumers follow althis kind of self interest they will consume extravagantly just to maximize their pleasure. They might be entraped in selfish behavior as well. In terms of online shoping they might tend to buy some items impulsively, and without consideration. Abdullah (2011) stressed that due to a low level of spirituality al-nafs al-ammarah exhibits negative characteristics and becomes self-centered. The Holy Quran (2: 90) says:

\footnotetext{
"Evil is that for which they sell their souls: that they should disbelieve in that which Allah hath revealed, grudging that Allah should reveal His bounty unto whom He will of His bondmen. They have incurred anger upon anger. For disbelievers is a shameful doom".
} 
IQTISHADIA

12,1

46

Turning to the second level, al-nafs al-lawwamah guides people to develop their social conciousness in a sense that they share part of their utility for social objectives. However, al-nafs al-lawwamah is an ambiguous mentality that often tends to material oriented as well. Hence, consumers behave with this self-interest will consume commercial goods remains to seek pleasure. Ubale and Abdullah (2015) stated that al-nafs al-lawwamah is the part of the soul that brands one to blame. It starts to consider the devinity aspect, but it tends to satisfies its interest to material things. That is way al-nafs al-lawwamah blames this condition. Yousofi (2011) identified this stage of al-nafs as the individual interest that is charaterized by constant awareness. The Holy Quran (75: 1-2) says:

"Nay! I swear by the Day of Resurrection. Moreover, nay! I swear by al-nafs al-lawwmah".

Finally, al-nafs al-muthmainnah (Quran 89: 27-28) as the highest level of self-interest guides people to internalize religious values in any economic action that is they are guided by Islamic norms. According to Rezaeitatalarposthi (2013) this nafs is the peaceful self that refers to peace and happiness in personality. Consumers with this self-interest will fit their spending in line with religious beliefs and norms so as to they do not consume extravagantly. They might also hold themselves to buy items impulsively and make a balance in satisfying both body and soul. The Holy Quran (28: 27) says:

"But seek the abode of the hereafter in that which Allah has given you and neglect not your portion of the world, and be kind even as God has been kind to you and seek not corruption in the earth".

Hence, this research proposes that religiousity improves self-interest from its lowest level to the highest one; from al-nafs al ammarah to alnafs al-muthmainnah. It means muslim consummers will transform their material orientation to spiritual ones.

Our study paid attention on this configuration in wich self-interest influenced by islamic religiosity. Hasan (2011) pointed out that in Islam selfinterest seems to be some sort of affinity in the moral conduct. In buying bahavior, Khayruzzaman (2016) stated that there was a strong relationship between religiosity in Islamic countries and consumption behaviour that influences their purchase decisions. 


\section{Self-Interest and Online Impulse Buying}

As an actualization of religiosity, self-interest exhibits extrinsic behavior in online impulse buying. Consumers tend to maximize their utility for commercial goods bought from e-commerce. When they decide to buy goods from online system they are often driven to realize their strong desire that leads them to spend money impulsively. Hofmann et. al. (2018) stated that strong selfish desire and weak moral standard and values can be dominant factor why people cannot resist their impulsive behavior. They stated that morality will mediate the effect of moralization of self-control.

In terms of self-interest configuration, it is proposed that self-interest will respond a tendency to ilmpulse buying differently. As Hoetoro (2017) stated that part of self-interest tends to maximise its utility and another part tends to resist from selfishness and fits an internal desire with religious norms. Hence, due to its high desire to enjoy pleasure al-nafs al-ammarah and alnasf al-lawwamah contribute consumers to buy impulsively while al-nafs al-muthmainnah will resist self-interest from impulse buying. Consumers who have al-nafs al-muthmainnah consider that they have to spend their money for the better in future live. The Holy Quran (57: 18) says:

"Surely, the man who gives alms, and the woman who gives alms and those who lend to Allah a goodly loan, it will be increased manifold for them, and theirs will also be a honorable reward".

\section{RESEARCH METHOD}

This research scrutinized and examined whether self-interest with its configurations has relationship with religiousity and impulse buying in online purchase context. For such a purpose, this study then employed 134 customers of e-commerce in Jakarta. The capital city of Indonesia was selected as research location because its high circulation of e-commerce. The data collected from questionnaires were analyzed by utilizing Smart-PLS, since the PLS approach gives minimal restrictions on sample size and residual distribution. The research was conducted during April and May 2018.

Departed from research objectives, the research framework used three constructs with multiple items to measure each of the construct. Items to construct impulse buying were adapted from Badgaiyan (2016), items for religiusity were constructed from Mokhlis (2009) and Worthington (2003), and self-interest configuration were taken from Hoetoro (2017). At initial step there were 19 indicators used for the constructs (see Appendixes). However,
Relationship between 
IQTISHADIA

12,1

when reliability test was conducted, some items must be removed from the constructs as can be reviewed on Tabel 1 as follows.

Table 1 Measurement Items; Factor Loadings, Composite Reliability, and Cronbach's alpha

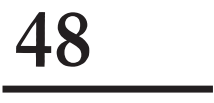

\begin{tabular}{cccc}
\hline Constructs \& Items & $\begin{array}{l}\text { Factor } \\
\text { Loadings }\end{array}$ & $\begin{array}{l}\text { Composite } \\
\text { Reliability }\end{array}$ & $\begin{array}{l}\text { Cronbach's } \\
\text { alpha }\end{array}$ \\
\hline $\begin{array}{c}\text { Impulse Buying } \\
\text { IB.1 }\end{array}$ & 0.761 & 0.798 & 0.621 \\
IB.2 & 0.652 & & \\
IB.3 & 0.709 & & \\
Religiusity & 0.765 & 0.894 & 0.843 \\
R.1 & 0.853 & & \\
R.2 & 0.835 & & \\
R.3 & 0.837 & & \\
R.4 & 0.931 & 0.889 & \\
al-Nafs al-Ammarah & 0.856 & & \\
NA.1 & & & \\
NA.2 & 1.000 & & \\
al-Nafs al-Lwwamah & & & \\
NL.2 & 0.000 & \\
Al-Nafs al-Muthmainnah & 0.736 & 0.791 & \\
NM.1 & & &
\end{tabular}

\section{Hypotheses}

Based on prior discussions, it is obviously percieved that self-interest (alnafs) plays an important role in regulating an inclination to shop e-commerce immpulsively. This come up with some hypotheses that religiousity and selfinterest have relationship with impulse buying. Hence, five hypotheses can be developed as follows:

Hypothesis 1: Islamic religiousity has negative relationship with online impulse buying.

Hypothesis 2: Islamic religiousity positively influences self-interest configuration.

Hypothesis 3: Al-nafs al-ammarah positively infulences online impulse buying.

Hypothesis 4: Al-nafs al-lawwamah positively influences online impulse buying.

Hypothesis 5: Al-nafs al-muthmainnah negatively influences online impulse buying. 


\section{Findings and Discussion}

The respondents of this research were taken from online customers in Jakarta. They had been asked through online questionary and then the respond from this online questinary were given by 134 respondents. The respondents' profile of this research is presented in Table 2 as follows:

Table 2. Respondents' Profile

\begin{tabular}{|c|c|c|}
\hline \multirow{2}{*}{ Category } & \multicolumn{2}{|c|}{ Respondents $(\mathrm{N}=134)$} \\
\hline & Frequency & Percentage (\%) \\
\hline \multicolumn{3}{|l|}{ Gender } \\
\hline Male & 40 & 29.9 \\
\hline Female & 94 & 70.1 \\
\hline \multicolumn{3}{|l|}{ Age } \\
\hline$<20$ & 27 & 20.1 \\
\hline $21-30$ & 91 & 67.9 \\
\hline $31-40$ & 10 & 7.6 \\
\hline $41-50$ & 3 & 2.2 \\
\hline $50>60$ & 3 & 2.2 \\
\hline \multicolumn{3}{|l|}{ Expenditure/month } \\
\hline $1.000 .000-3.000 .000$ & 72 & 53.8 \\
\hline $3.001 .000-5.000 .000$ & 31 & 23.1 \\
\hline $5.001 .000-7.000 .000$ & 31 & 23.1 \\
\hline \multicolumn{3}{|l|}{ Value of transaction } \\
\hline$<500.000$ & 70 & 52.2 \\
\hline $500.000-1.000 .000$ & 40 & 29.9 \\
\hline $1.001 .000-2.000 .000$ & 15 & 11.2 \\
\hline $2.001 .000-3.000 .000$ & 4 & 3.0 \\
\hline$>3.000 .000$ & 5 & $3 \cdot 7$ \\
\hline Total & 134 & 100.0 \\
\hline
\end{tabular}


IQTISHADIA

12,1
In terms of respondents' age, the respondents centered around the productive age, that is in between 20-40 years old. As many as $88 \%$ of respondents aged around 21-30 years and 7.6\% of respondents are in the age of 31-40 years. The age distribution of respondents indicated that online customers are categorized as young segment of e-commerce customers. It might be caused by an increasing trend among young generation that customized themselves with internet.

Meanwhile, the level of expenditure paid by the respondents showed that the respondents can be categorized as middle income level of customers. They spended their money for consumption per month in between Rp3.000.000 to Rp7.000.000. Finally, the value of e-commerce transaction has been dominated below Rp500.00o by $52.2 \%$ repondents, around Rp1.000.000 by $29.9 \%$ respondents, and more than Rp2.000.000 by $17.9 \%$ respondents.

\section{The Interrelation among Variables}

The efficacy of IWE in strengthening firms' performance of CBR was tested by using Partial Least Square (PLS) method. The findings then were calculated by using Smart-PLS as presented in Figure 1 and Table 4 as follows:

Figure 1 Research Findings

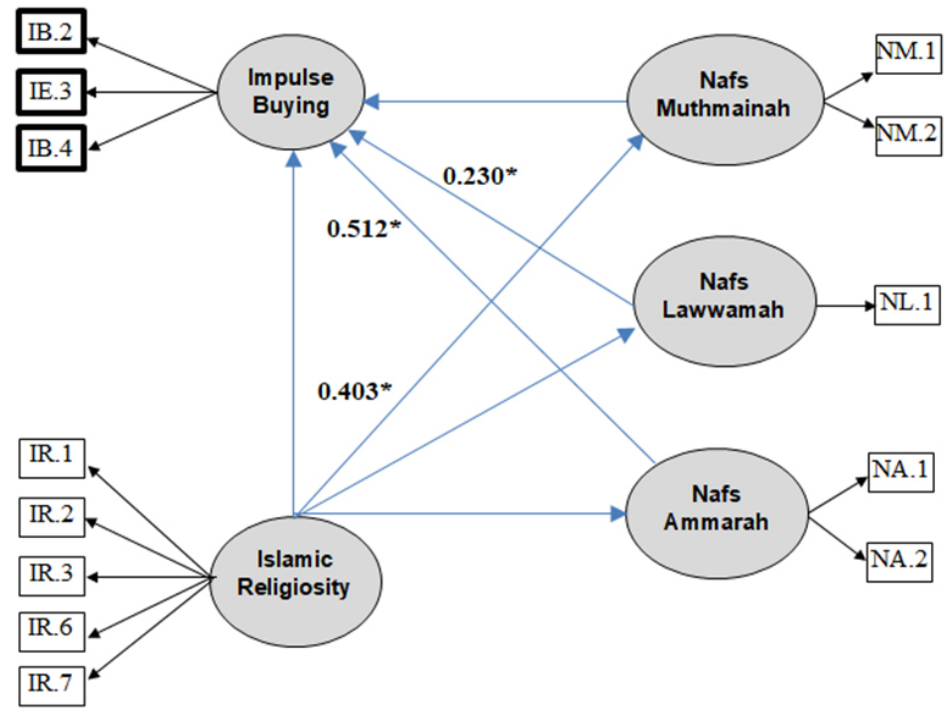

Tabel 3 Inner Model and Hypotheses Testing

\begin{tabular}{ccccccc}
\hline $\begin{array}{c}\text { Inter-Variabel } \\
\text { Relationship }\end{array}$ & Coefficient & Mean & SD & $\begin{array}{c}\text { T } \\
\text { Statistic }\end{array}$ & $\begin{array}{c}\text { P } \\
\text { Values }\end{array}$ & Significance \\
\hline $\begin{array}{l}\text { Nafs Ammarah } \rightarrow \\
\text { Impulse Buying }\end{array}$ & 0.512 & 0.510 & 0.012 & 5.045 & 0.000 & Significant \\
\hline
\end{tabular}




\begin{tabular}{|c|c|c|c|c|c|c|}
\hline $\begin{array}{l}\text { Nafs Lawwamah } \\
\text { Impulse Buying }\end{array}$ & 0.230 & 0.221 & 0.120 & 1.911 & 0.057 & Significant* \\
\hline $\begin{array}{l}\text { Nafs Mutmainah } \rightarrow \\
\text { Impulse Buying }\end{array}$ & -0.001 & -0.016 & 0.089 & 0.006 & 0.995 & Not Sig \\
\hline $\begin{array}{l}\text { Islamic Religiosity } \rightarrow \\
\text { Impulse Buying }\end{array}$ & 0.074 & 0.083 & 0.093 & 0.788 & 0.431 & Not Sig \\
\hline $\begin{array}{l}\text { Islamic Religiosity } \rightarrow \\
\text { Nafs Ammarah }\end{array}$ & 0.131 & 0.110 & 0.124 & 1.049 & 0.295 & Not Sig \\
\hline $\begin{array}{l}\text { Islamic Religiosity } \rightarrow \\
\text { Nafs Lawwamah }\end{array}$ & 0.004 & -0.000 & 0.117 & 0.031 & 0.975 & Not Sig \\
\hline $\begin{array}{l}\text { Islamic Religiosity } \longrightarrow \\
\text { Nafs Mutmainah }\end{array}$ & 0.403 & 0.421 & 0.083 & 4.855 & 0.000 & Significant \\
\hline
\end{tabular}

\section{Islamic Religiosity and Impulse Buying}

Hypothesis 1 is proposed to find an answer of the relationship between Islamic religiosity and impulsebuying. It is stated that Islamic religiosity negatively influences impulse buying. The result of PLS (Table 3) shows this relation, in fact, is not significant. The reason might be addresed that Islamic religiosity in this case is simply a knowledge that is not actualized in practice. Religious beliefs need to be practised in daily living. According to Muhammad and Mizerski (2010) that a religion consists of religious commitment, religious knowledge, and religious orientation that are implemented equally. However, Musadik and Azmi (2017) pointed out that previous researches on the relationship between Islamic religiosity and impulse buying is still inconsistent. A part of the resarches provide positive relationship and another part shows negative one. The result of this study showed insignificant relationship between Islamic religiosity and impulse buying.

\section{Islamic Religiosity and Self-Interest Configuration}

Hypothesis 2 is proposed to find an answer that Islamic religiosity configurates the levels of self-interest among muslim customers. As it is formulated that self-interest which so called as al-nafs in Islamic economics is not single dimension but it varies with certain levels, this research examines in what level Islamic religiosity influences self-interest. By viewing the Table 3, PLS calculation provided a result that Islamic religiosity positively influences al-nafs al-muthmainnah (path coefficient $=0.403 ; \mathrm{p}$-value $=0.000<0.05 ; \alpha=5 \%$ ). When customers improve their understanding on Islamic religiosity it will help them to behave with concern to the non-material oriented. Their consumption is guided by religious beliefs and norms; they will retain themselves from impulse buying as muslim customers have to make a balance between material and spiritual orientation. 
IQTISHADIA

12,1

52

Meanwhile, the influence of Islamic religiosity to al-nafs alammarah and al-nafs al-lawwamah is not significant. According to Baharuddin and Ismail (2015) to reach the level of al-nafs almuthmainnah, an individual has to clean up the domain to obey the laws of Allah, leave the prohibitations of Allah, and appreciates the commendabel behaivor in everyday life such as avoid the wasted consumption.

\section{Al-Nafs al-Ammarah and Impulse Buying}

The results of PLS calculation showed that al-nafs al-ammarah has positive relationship with online impulse buying (path coefficient $=0.512 ; \mathrm{p}$-value $=0.000<0.05 ; \alpha=5 \%$ ), then hypothesis 3 was accepted. Since al-naf al-ammarah is material oriented, when consumers increase their interest in material orientation they will buy more impulsively. Consumers with this lowest level of self-interest cannot resist their strong desire in online impulse buying. They tends to spend extravagantly with unplanned buying. Rothman and Coyle (2018) pointed out that al-nafs al-ammarah refered to a state in wich a person is not exerting concerted effort in controlling his/her interest and allowing the lower self to run wild.

\section{Al-Nafs al-Lawwamah and Impulse Buying}

The results of PLS calculation showed that al-nafs al-lawwamah has positive relationship with online impulse buying (path coefficient $=0.230 ; p$-value $=0.057>0.05 ; \alpha=10 \%$ ), then hypothesis 4 was accepted. Here, the configuration of self-interest begins to emerge. In terms of Islamic teaching al-nafs al-lawwamah still expresses material oriented. However, it tends to spiritual aspect that can be expressed by its weak significant $(\alpha=10 \%)$. This significant shows that although al-nafs al-lawwamah is still material oriented, it tends to spiritual oriented as well. According to Ahmad and Hassan (2015) this nafs in the midle range expedition and perfection. In describing the stage of soul, however, Rothman and Coyle (2018) stated that alnafs al-lawwamah is in stage of spiritual learning (tahdib al-akhlaq). Throughout its life in this world, there exists a dynamic interplay of conflicting forces that determines an individual to reach alignment or misalignment with fitrah. 
The result of PLS calculation showed that al-nafs al-Muthmainnah is not significant with online impulse buying (path coefficient $=-0.001$; p-value $=0.995>0.05 ; \alpha=5 \%$ ), then hypothesis 5 was rejected. Here, self-interets reaches the top of the soul. In Islamic perspective this type between of self-interets tends to behave spiritually than materially throughout this life. That is way consumers with al-nafs al-muthmainnah will avoid impulse buying in their shopping patterns. According to Syed Agil (2007) this nafs will drive an economic man to achieve happienss as he or she succeeded in balancing the need of body and spiritual dimensions. Munsoor (2015) stressed this type of self-interest is now at rest in complete submission to the will of Allah. Moreover, Rothman and Coyle (2018) stated that al-nafs al-muthmainnah succeeded to reach Godly nature of the ruh and come more in alignment with the soul's state of fitrah.

\section{CONCLUSION}

In light with the above discussions, this study concluded that self-interest is not a single entity. It is not based on Bentham's rationality in which selfinterst always to seek pleasure and to avoid pain, but it has three dimensions. In Islamic perspective, self-interest that is usually called as al-nafs consists of al-nafs al-ammarah, al-nafs al-lawwamah and al-nafs al-muthmainnah. The first two tend to follow Bentham's rationality, whereas the last one moves beyond material orientation. In case of impulse buying among customers' bahavior, the study showed that al-nafs al-ammarah and al-nafs al-lawwamah have positive relationship with impulse buying, while al-nafs al-muthmainnah was not significant with impulse buying. The result proved that in order to minimize a habit of impulse buying, customers have to develop their self to reach al-nafs al-muthmainnah. The result also showed that there is a need to elaborate an essence of self-interest as Islam teachs about it.

\section{References}

Abdullah, F. (2011). Human Behavior from an Islamic Perspective: Interaction of Nature, Nurture, and the Spiritual Dimension. American Journal of Islamic Social Sciences. Volume 28 Number 2: 86-105. 
IQTISHADIA

12,1

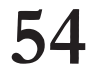

Ahmad, R and Hassan, S.A. (2015). Tazkiyatun Nafs (Purification of the Soul): A Psycho - Spiritual Approach in Strengthening Marriage Relationships. Exlicir Social Sciences 83: 33239-33242.

Akram, U., Hui, P., Khan, M.K., Tanveer, Y., Mehmood, K., and Ahmad, W. (2018). How website quality affects online impulse buying: Moderating effects of sale promotion and credit card use. Asia Pacific Journal of Marketing and Logistics. Vol. 30 No. 1: 235-256.

Akram, U., Hui, P., Khan, M.K., Hashim, M., and Rasheed, S. (2016). Impact of Store Atmos-phere on Impulse Buying Behaviour: Moderating Effect of Demographic Variables. International Journal of $u$ - and e-Service, Science, and Technology. Vol 9 No 7: 43-6o.

Alam, S. S., Mohd, R., and Hisham, B. (2011). Is religiosity an important determinant on Muslim consumer behaviour in Malaysia? Journal of Islamic Marketing. Vol. 2 No.1: 83-96.

Aliman, N.K., Arifin, Z.Z., and Hashim, S.M. (2018). Religiosity Commitment and Decision-Making Styles Among Generation Y Muslim Consumers in Malaysia. International Journal of Academic Researh in Business \& Social Sciences. Vol. 8 No. 1: 554-576.

Arjuna, L.H., Nasution, M.Y., and Yusuf, M. (2017). The Effect of Islamic Religiosity, Islamic Motivation, and Islamic Work Ethics to Islamic Leadership Sharia Financial Institutions in Gorontalo Province, Indonesia. IOSR Journal of Humanities and Social Science. Volume 22 Issue 8: 82-87.

Badgaiyan, A. J., Verma. A., and Dixit., S. (2016). Impulsive buying tendency: Measuring important relationships with a new perspective and an indigenous scale. IIMB Manage-ment Review 28: 186-199.

Baharuddin, E and Ismail, Z. (2015). 7 Domains of Spiritual Intelligence from Islamic Perspective. Procedia. Social and Bahavioral Sciences (211): 568-577.

Borzooei, M and Asgari, M. (2014). The Effect Reigious Commitment on Halal Brand Relation and Purchase Intention.

Farooq, M. (2011). Self-Interst, Homo Islamicus and some Behavioral Assumptions in Islamic Economics and Finane. Electronic copy of article is available at: http//ssrn.com/ abstract $=1740729$.

Fiori, M. (2009). A New Look at Emotional Intelligence: A Dual Process Framework. Personality and Social Psychology Review 13: 21-44.

Franco, E., and Bulomine, R S. (2016). Advantages and Challenges of E-Commerce Customers and Business: in Indian Perspective. International Journal of Research Grantaalayah. Vol. 4: 7-13. 
Gebaur, J.E., Sedikides, C, Schonbrodt, F.D., Bleidorn, W, Rentfrow, P.J., Potter, J., and Goslng, S.D. (2016). The Religiosity as Social Value Hypothesis: A Multi Method Replication and Extention across 65 Countries and Three Levels of Spatial Aggre-gation. Journal of Personality and Social Psychology.

Hamzah, R., Kamarudzaman, Md.I., and Janor, M. R. (2010). Spiritual Education Development Model. Journal of Islamic and Arabic Education 2 (2): 1-12.

Hasan, Z. (2011). Scarcity, self-interest and maximization from Islamic angel. MPRA Paper No. 29414.

Hidayatullah, A., Sail., S. I., Masykur, I. G., and Hadi, F. (2012). At-Thayyib al-Quran Transliterasi per Kata dan Terjemah per Kata. Cipta Bagus Segara. Bekasi.

Hill, R and Myatt, T. (2010). The Economics Anti-Textbook A Critical Thinker's Guide to Microeconomics. Fernwood Publi-shing Ltd, Canada.

Hoetoro, A. (2017). Ekonomi Islam: Perspektif Historis dan Metodologis. Empat Dua, Intrans Publishing. Malang.

Hofmann, W., Meindl, P., Mooijman, M., and Graham, J. (2018). Morality and Self-Control: How They are Intertwined and where They Differ.

Katadata. (2018). Berapa Pangsa Pasar e-Commerce Indonesia? datapublish/2017/10/13/berapa-pangsa-pasar-e-commerceindonesia.

Khayruzzaman. (2016). Impact of Religiosity on Buying Behavior of Financial Products: A Literature Review. International Journal of Finance and Banking Research 2(1): 18-23.

Koole, S.L, McCullough, ME., Kuhl, J., and Roelofsma, P. (2010). Why Religion's Burden are Light: from Religiosity to Implicit SelfRegulation. Personality and Social Pschology Review 14(1): 95-107.

Ling, LP., and Yazdanifard, R. (2015). What Internal and External Factors Influence Impulsive Buying Behavior in Online Shopping? Glabal Journal of Management and Business Research. 15(5): 25-32.

Mathai, S. T., and Haridas, R. (2014). Personality-its impact on impulse buying behaviour among the retail customers in Kochin city. IOSR Journal of Business and Management Volume 16 Issue 4: 48-55.

McCleary, R.M., and Barro, R.J. (2006). Religion and Economy. Journal of Economic Perspective. Volume 20 Number 2: 49-72. 
IQTISHADIA

12,1

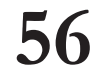

Mokhlis, S. (2009). Relevancy and Measurement of Religiosity in Consumer Behavior Research. International Business Research. Vol. 2 No. 3: 7584.

Muhammad, N and Mizerski, D. (2010). The construct medeating religion' inflence on buyers and consumers. Journal of Islamic Marketing 1(2): 124-135.

Munsoor, M.S. (2015). The Soul (Hearth) and its Attributes: an Islamic Perspective with Reference to Self in Western Pschology. Afkar 16: 93-118.

Musadik, S.H.S.A, and Azmi, I. A. G. (2017). A Conceptual Paper: the Effect of Islamic Religiosity on Impulse Buying Behavior. Journal of Global Business and Social Entre-preneurship. Vol.1 No. 2: 137-147.

Pradipto, Y.D., Winata, C., Murti, K., and Azizah, A. (2016). Think Again Before You Buy: The relation beteen self-regulation and impulsive buying behaviors among Jakarta young adults. Procedia. Social and Behivoral Sciences 222: 177-185.

Rook, D. W., and Fisher, J. R. (1995). Normative Influences on Impulsive Buying Behavior. Journal of Consumer Research. Vol. 22: 305-313.

Rezaeitalarposthi, A. (2013). Psychology from Islamic Perspective: Contributions of Quran to Contemporary Psychologists. International Research Journal of Applied and Basic Sciences. Vol 6 (11): 1590-1595.

Rothman, A and Coyle, A. (2018). Toward a Framework for IslamicPsychology and Psychotherapy: An Islamic Model of the Soul. Journal of Religion and Health.

Sedikides, C and Gebauer, J.E. (2010). Religiosity as Self-Enhancement: A Meta-Analysis of the Relation between Socially Desirable Responding and Releigiosity. Personalty and Social Psychology Review 14(I): 1736.

Shih-Lo, L. Y., Lin, S-W., and Hsu, L-Y. (2016). Motivation for online impulse buying: A two-factor theory perspective. International Journal of Information Management 36: 759-772.

Singh, S., and Verma, H. (2018). A Comprehensive Structural Equation Modeling for E Impulse Buying. Academy of Marketing Studies Journal. Vol. 22 Issue. 1: 1-14.

Syed Agil, S.O. (2007). Psychological behavior and economics: the need for new theories and redifinition of basic concepts in Islamic economics. Unitar-E Journal Vol 3 No 1: 76-90. 
Ubale, A. Z., and Abdullah, A. H. (2015). The Effects of Spirituality in Shaping the Human Behaviour (an Islamic Perspective). International Journal of Academic Research in Business and Social Sciences. Vo. 5 No. 9: 1-13.

Verplanken, B and Sato, A. (2011). The Psychology of Impulse Buying: an Integrative Self-Regulation Aproach. Journal of Consumer Policy 34: 197-210.

Vriend, N.J., (1996). Rational behavior and economic theory. Journal of Economic Behavior and Organisation. Vol. 29: 263-285.

Worthington, E.L., Wade, N.G., Height, T.L., Ripley, J.S., McCullough, M.E., Berry, J.W., Schmitt, M.M., Berry, J,T., and Bursley, K.H. (2003). The Religious Commitment Inventory-10: Develepment, Refinement, and Validation of a Brief Scale for Research and Conseling. Journal of Conseling Psychology. Vol. 50 No. 1: 84-96.

Yousofi, H. (2011). Human health and religious practices in Quran. Procedia - Social and Behavioral Sciences 30: 2487-2490. 